\title{
Vulnerability of Rural Areas to Climate Change - Analysis of Similar Units in Terms of Spatial Conditions for Warmińsko-Mazurskie Voivodeship
}

\author{
Katarzyna Kocur-Bera' \\ 1 University of Warmia and Mazury in Olsztyn, Faculty of Geodesy, Geospatial and Civil Engineering, Institute \\ of Geoinformation and Cartography, ul. Oczapowskiego 2, 10-719 Olsztyn, Poland \\ e-mail: katarzyna.kocur@uwm.edu.pl
}

\begin{abstract}
In the current decade, the fact that climate change is a continuous process and that humans have been contributing to this change is indisputable. Therefore, the whole society and the decision-makers who guide the process of application of regional policy principles, are facing a challenge as to which measures need to be taken to minimise the consequences of this change. Although we live in a global world, it can be observed that interactions occur in each unit on an individual basis. As we have more and more knowledge and information on the space, we can indicate which units, regions and spaces have the greatest predisposition to be subject to climate change. Moreover, being aware of the level of risk, we can attempt to implement tools that will help society to accept climate change and properly adapt to it. A space's predisposition to climate change is not only determined by the weather, environmental or geographical conditions. The literature on the subject indicates three basic determinants of the predisposition, i.e. the exposure, vulnerability and the adaptive capacity. Only all of these elements grouped together can provide an answer to the question about a unit's predisposition. The article focuses on the indices which represent all three determinants of the predisposition. It should be noted that depending on the availability of data and their aggregation, there is no possibility of using the same indices for all countries. This, however, does not prevent the performance of a uniform analysis for spaces included in the same statistics. The article presents a case study for agricultural land in the province of Warmia and Mazury. Using Ward's method, four subregions with similar determinants of the predisposition to climate change were distinguished. Three subregions stand out, as two of them have a significant impact of exposure (S.1) and vulnerability (S.2), while the third subregion dominates in terms of adaptive capacity (S.4).
\end{abstract}

Keywords: climate change, exposure, vulnerability, space's adaptive capacity

\section{INTRODUCTION}

The ongoing climate change results from two groups of factors: external and internal. The external factors are related inter alia to changes in solar radiation [Kundzewicz, 2011], while the internal factors are those marked on the Earth by the existence of humans (atmospheric composition change, greenhouse gas emissions to the atmosphere, changes in the Earth's surface properties) [Błażejczyk, Żmudzka, 2013; IPCC, 2018; Coumou, Rahmstorf, 2012]. Climate change will affect space in different ways, depending on the location. According to the European Environment Agency, Poland, along with a part of the European continent, is at risk of, inter alia, rising temperatures, reduced precipitation in the summer, and floods and fires in forest areas [EEA, 2017]. The consequences of climate change include natural disasters and extreme events [Kocur-Bera, 2015]. International statistics kept since the beginning of the 20th century indicate that both the number (Fig. 1) and the economic financial losses caused by natural disasters (Fig. 2) have significantly increased over the past five decades [Ritchie, Roser, 2019]. Having knowledge confirmed by data, organisations and government have taken a decision to implement measures aimed at tackling climate change (mitigation) to the greatest extent 
possible, and adaptation in other situations. Both mitigation and adaptation require an assessment of the level of threat to the space and society as well as of the potential (power, strength) allowing the planned measures to be introduced.
The literature on the subject indicates numerous lines of research into the ongoing climate change in the form of indices. They belong both to the area of measurement of changes and anomalies of meteorological indices observed over the

\section{Global reported natural disasters by type}

The annual reported number of natural disasters, categorised by type. This includes both weather and non-weather related disasters.

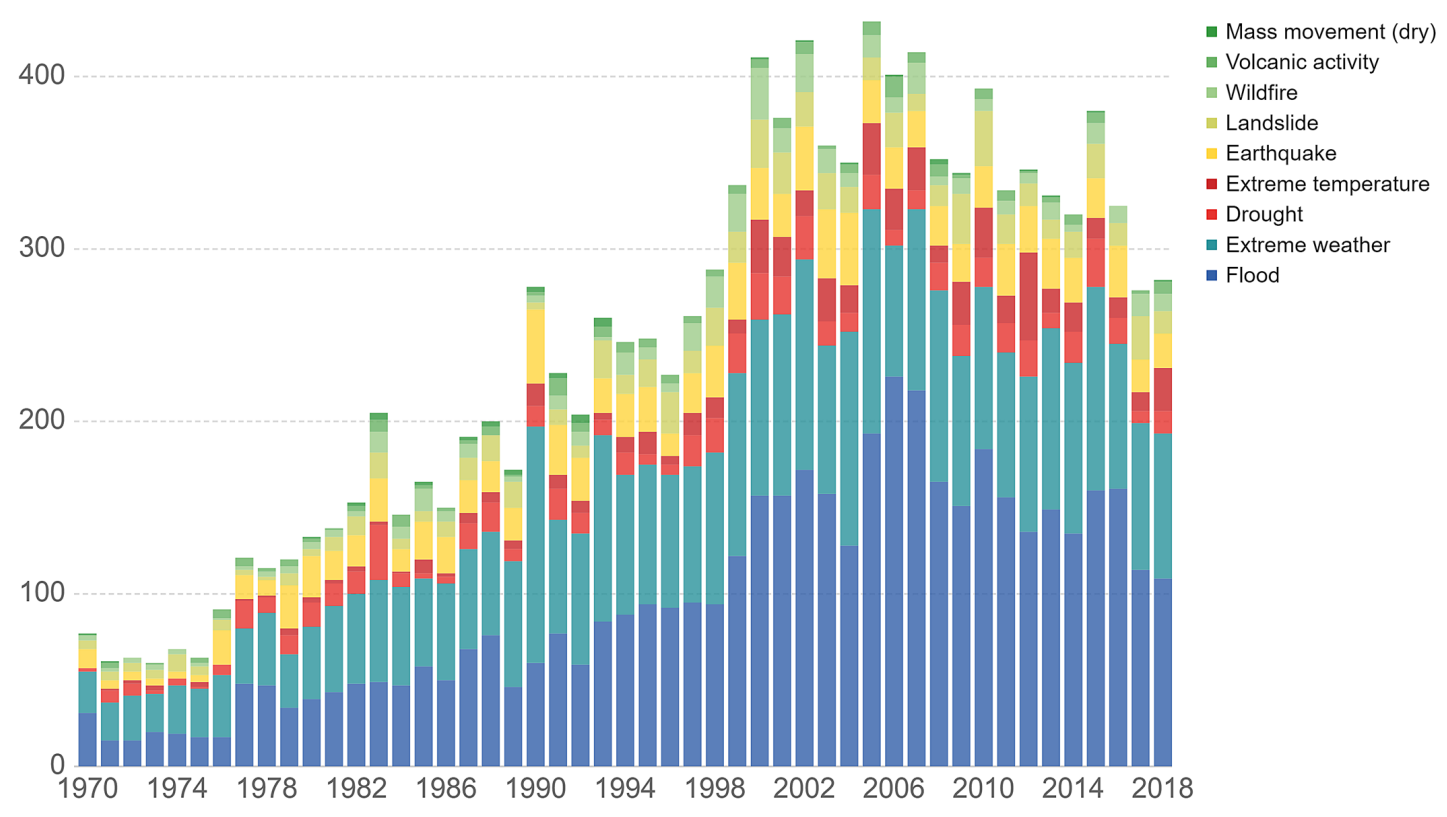

Source: EMDAT (2017): OFDA/CRED International Disaster Database, Université catholique de Louvain - Brussels - Belgium OurWorldlnData.org/natural-disasters • CC BY

Fig. 1. Global reported natural disasters by type and economic damage [Ritchie, Roser, 2019]

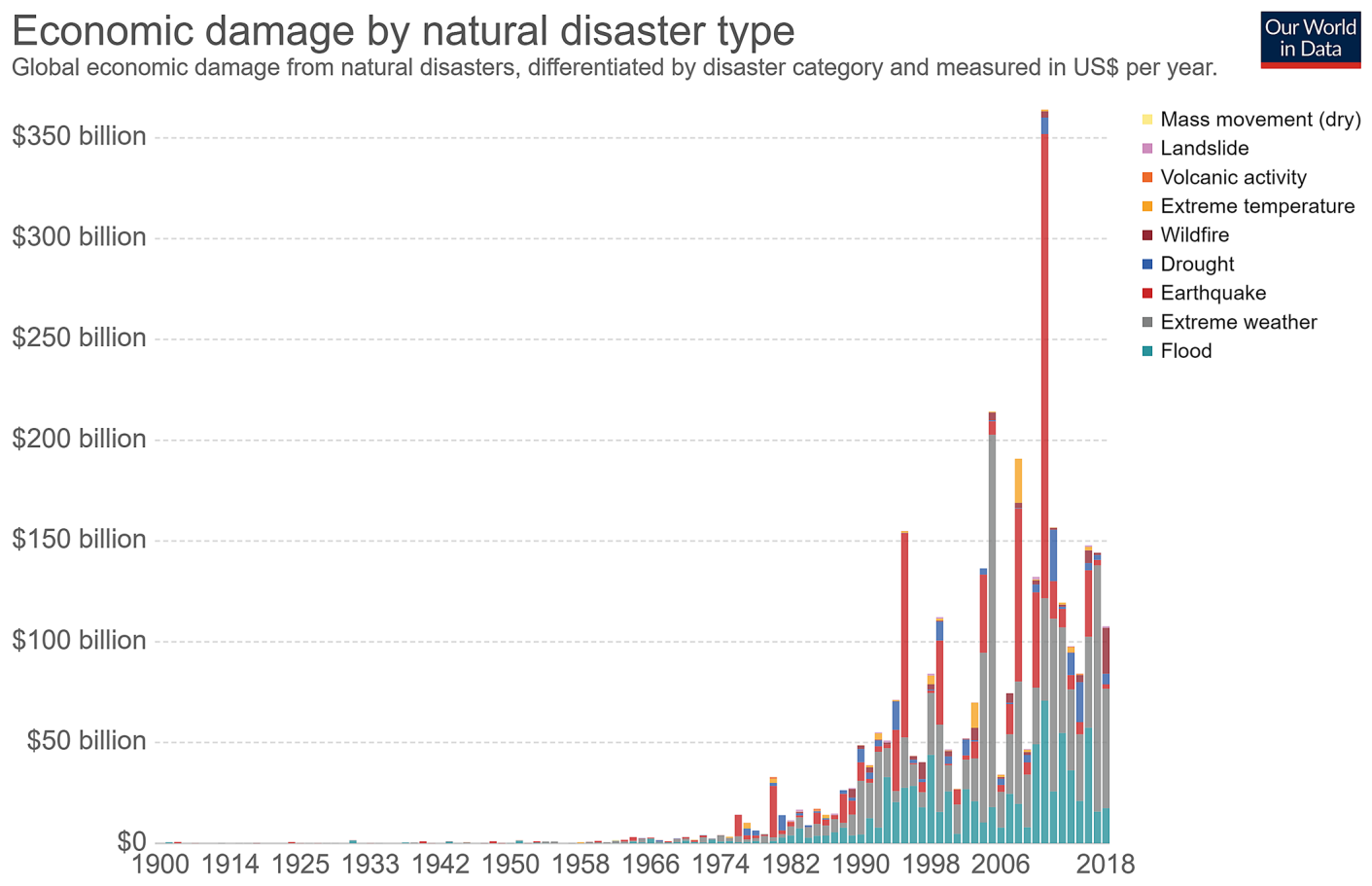

Source: EMDAT (2019): OFDA/CRED International Disaster Database, Université catholique de Louvain - Brussels - Belgium OurWorldlnData.org/natural-disasters • CC BY

Fig. 2. Global reported natural disasters by type and economic damage [Ritchie, Roser, 2019] 
decades (e.g. Global Climate Risk Index, Physical Vulnerability to Climate Change, etc.). Certain researchers, while studying the indices, draw attention to the environmental, economic and social potential (e.g. Climate Vulnerability Index, Socioeconomic Vulnerability Index, etc.), which affects the possibilities for preventing changes and introducing adaptation measures. The current study focused on the factors which affect the unit's vulnerability/predisposition to climate change, and which are a part of risk reduction.

The concept of "vulnerability" includes the natural (environmental, economic) and social predispositions of the analysed spatial units [Cardona et al., 2012]. A system's resilience to climate change is determined by the exposure, physical surroundings, the system's vulnerability, and the capacity to adapt to the ongoing changes in both economic and social terms [Granados, 2012]. The greater a system's adaptive capacity, the higher the probability that it is able to handle the ongoing climate change, and the less it is vulnerable to this change [Bryan et al., 2013].

Many countries have drawn up adaptation plan documents; for example, in Poland such a document has been prepared by the Ministry of the Environment [Kocur-Bera, 2018]. These documents provide guidelines and operating procedures for various regions, e.g. for the coastal zone or the inhabited zone. They do not take into account, however, the geographical diversity or the particular determinants occurring in macroregions in economic or social terms. Meanwhile, information on the level of risk and susceptibility to these hazards provided directly to citizens and concerning their places of residence or work allows them to decide to broaden their knowledge on the possibilities of applying adaptation and prevention solutions.

Since no formal methodology for the determination of spatial units' predisposition to climate change has been approved to date, therefore this task presents an enormous challenge to researchers and offers a wide range of opportunities.

Many authors of scientific studies indicate that while studying vulnerability, social, economic and environmental factors need to be taken into account [Polsky et al., 2007]. This allows the research to be conducted independently from climate models, as these models change frequently and the forecasting accuracy has a high degree of uncertainty [Hahn et al., 2009]. According to Sridevi et al. [2014], the vulnerability of rural areas is a function of socio-demographic, occupational and resource factors as well as the agricultural land's potential. Żurovec et al. [2017] takes into account the exposure (temperature and precipitation changes, flood hazard, etc.), vulnerability (related mainly to the society) and adaptive capacity in terms of income, educational level, medical care and social capital. Ludena and Won Yoon [2015] showed three predisposition aspects: exposure, vulnerability and adaptive capacity, and divided them into particular economic, social, infrastructural and governmental factors. On the other hand, Hiremath and Shiyni [2013] focus mainly on demography, climatic variables, variables that specify conditions in areas used for agricultural purposes, and employment opportunities in non-agricultural sectors.

The aim of this study was to cluster the factors representing rural areas' predisposition to climate change. Three main areas of predisposition were taken into account, i.e. the exposure, vulnerability and adaptive capacity, which are most often mentioned in the literature on the subject. The measures considering the analysed domains were selected based on the availability of data and their accumulation for the analysed administrative unit. The study used the average financial losses in agricultural crops per hectare of agricultural land from the years 2010-2017, collected for the purposes of a so-called disaster loan, which replaced the features characterising the changing climate. This helped obtain the direct effect of meteorological variables on agricultural crops and not lowaccuracy forecasts. The study was conducted for 19 poviats (Poland's administrative units) while omitting two cities classified as poviats.

\section{MATERIALS AND METHODS}

The study covered the area of the province of Warmia and Mazury. In the north-south direction, the province stretches over a distance of $146 \mathrm{~km}$ i.e. $1^{\circ} 18^{\prime} 44^{\prime \prime}$. In the east-west direction, the province stretches for $240 \mathrm{~km}$ which, in terms of angular measure, is equal to $3^{\circ} 39^{\prime} 28^{\prime \prime}$. The province occupies an area of $24,173.47 \mathrm{~km}^{2}(7.7 \%$ of the area of Poland) inhabited by 1.45 million people. The average population density is among the lowest in the country and amounts to 60.06 people per $\mathrm{km}^{2}$ (compared to the average Polish population density of 123.24 people per $\mathrm{km}^{2}$ ). In rural areas of the analysed region, it amounts to approx. 25 
people per $\mathrm{km}^{2}$. Forests cover almost $30 \%$ of the province area. The geodetic area of agricultural land in the region exceeds 1.3 million ha, which accounts for $55 \%$ of the province area (all of Poland $-61 \%$ ), the other part is occupied by forest land and wooded land $-32 \%$, waters $-6 \%$, builton areas $-3.5 \%$, and other land $-3.5 \%$. Rural areas in the province cover an area of 2,359.6 thousand ha, i.e. $97.5 \%$ of the province area, which accounts for the greatest percentage in the country. The province of Warmia and Mazury is divided into 21 poviats (including two cities classified as poviats, i.e. Olsztyn and Elbląg). The region of Warmia and Mazury is distinguished on both the national and European scales by its diversity and richness of natural environment, which includes varied terrain, numerous lakes, dense forest complexes and clean air. Half of the province area is under legal environmental protection, including areas of international significance (NATURA 2000). The region has a well-developed network of surface waters comprising numerous lakes, water holes, rivers, canals and a part of the Vistula Lagoon (5.7\% of the province area).

The data for the study were acquired from Provincial Agricultural Advisory Centre (ODR) in Olsztyn (data on financial losses in agricultural crops in the years 2010-2018 - see Figure 3), from the Local Data Bank, and from summaries and results of studies conducted and published by other researchers. Certain indices, e.g. the percentage of rural inhabitants, medical care, or road density were calculated based on available data (acquired inter alia from Statistics Poland (GUS)). The study took into account 17 indices that represent the space's predisposition to climate change. The selection of indices was the result of relevant literature analysis and the availability of aggregated data. The main assumption behind the selection of the group of attributes was the consideration of the three aspects of a space's vulnerability to climate change, i.e. exposure, vulnerability and adaptive capacity. Each of the components making up the vulnerability comprised from two to seven indices. Table 2 summarises the indices taken into account in the study along with their origin sources and the adopted unit, while Table 2 shows the basic parameters describing selected attributes.

The clustering of unit vulnerability to climate change was carried out based on a dendrogram using the agglomeration by Ward's method (using the Euclidean distance - see formula 1).

$$
\begin{gathered}
d(A, B)=\sqrt{\left(x_{1 A}-x_{1 B}\right)^{2}+\left(x_{2 A}-x_{2 B}\right)^{2}+\cdots+} \\
\left(x_{n A}-x_{n B}\right)^{2}=\sqrt{\sum_{i=1}^{n}\left(x_{i A}-x_{i B}\right)^{2}}
\end{gathered}
$$

where: $d(A, B)$ - Euclidean distance;

$x_{A}$ - the beginning of the analysed section;

$x_{B}$ - the end of the analysed section.

This method allows clusters, i.e. disjoint observation subsets inside which observations are, in some specific sense, close to each other, to be detected in an observation set. In the analysed case, poviats with similar determinants represented by

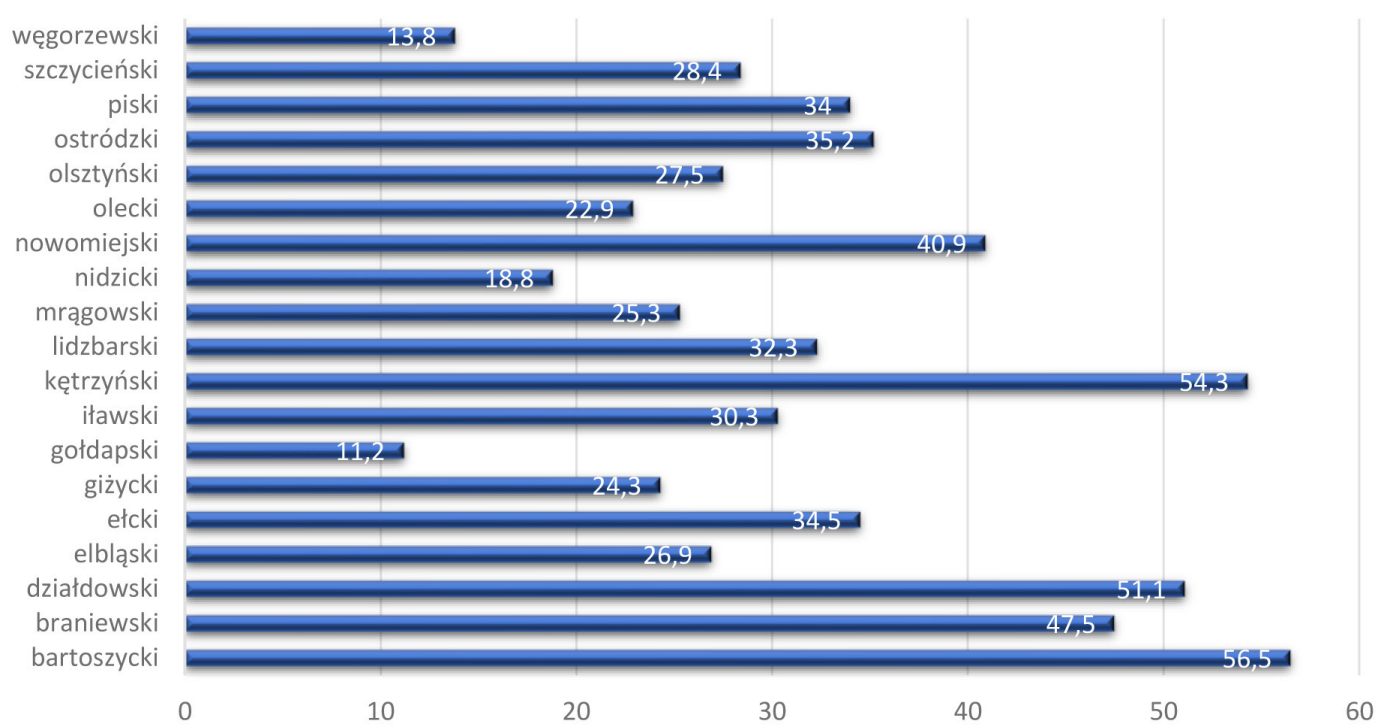

Figure 3. Financial losses (in million PLN) noted in the years 2010-2018 in particular poviats of Warmia and Mazury due to extreme events in areas under agricultural cultivation (drought, hail, hurricane, spring ground frosts, adverse effects of over-wintering, lightning strikes, floods and torrential rains) [based on the Agricultural Advisory Centre's (ODR), data from 2018] 
Table 1. A description of variables including the unit and the source of data origin

\begin{tabular}{|c|c|c|c|}
\hline Symbol & Feature & Unit & Source \\
\hline $\mathrm{X} 1$ & Financial losses in the years $2010-2018$ & $\begin{array}{l}\text { PLN/ha of agricultural } \\
\text { land }\end{array}$ & $\begin{array}{l}\text { ODR (2018) for the purposes of } \\
\text { disaster loan }\end{array}$ \\
\hline $\mathrm{x} 2$ & Agro-climatic condition & index & Acc. to Rudnicki, Kluba (2014) \\
\hline $\mathrm{X} 3$ & Agricultural Production Space Ratio & index & Acc. to Rudnicki, Kluba (2014) \\
\hline $\mathrm{X} 4$ & Agricultural land in the total poviat area & $\%$ & Local Data Bank, 2019 \\
\hline $\mathrm{X} 5$ & Rural population & $\%$ & Local Data Bank, 2019 \\
\hline $\mathrm{X} 6$ & Average monthly salary in agriculture & PLN & Local Data Bank, 2019 \\
\hline $\mathrm{X} 7$ & $\begin{array}{l}\text { Employment - agriculture, forestry, hunting and } \\
\text { fisheries }\end{array}$ & $\%$ & Local Data Bank, 2019 \\
\hline $\mathrm{x} 8$ & Unemployment rate & $\%$ & Local Data Bank, 2019 \\
\hline $\mathrm{X} 9$ & GDP per capita & PLN & Ciołek et al. (2018) \\
\hline $\mathrm{X} 10$ & Population with tertiary education & $\%$ & Local Data Bank, 2019 \\
\hline $\mathrm{X} 11$ & Education (schools per poviat) & number & Local Data Bank, 2019 \\
\hline $\mathrm{X} 12$ & Medical care & Number/1000 inhabitants & Local Data Bank, 2019 \\
\hline $\mathrm{X} 13$ & Density of poviat and local roads & $\mathrm{km} / 100 \mathrm{~km} 2$ & Local Data Bank, 2019 \\
\hline $\mathrm{X} 14$ & $\begin{array}{l}\text { Main crop yields (rye, wheat, triticale, barley, } \\
\text { cereal mixtures) }\end{array}$ & $\mathrm{dt} / \mathrm{ha}$ & ODR (2016) \\
\hline $\mathrm{X} 15$ & Urbanisation rate & $\%$ & Local Data Bank, 2019 \\
\hline $\mathrm{X} 16$ & National economy entities & $\begin{array}{l}\text { Number/10000 } \\
\text { inhabitants }\end{array}$ & Local Data Bank, 2019 \\
\hline $\mathrm{X} 17$ & $\begin{array}{l}\text { Social capital including the number of foundations, } \\
\text { social participation in public events and in } \\
\text { governmental elections }\end{array}$ & index & Pawlewicz (2016) \\
\hline
\end{tabular}

Table 2. Summary of basic statistics for the analysis's variables

\begin{tabular}{|c|c|c|c|c|c|c|}
\hline & Average & Mediana & Min. & Max. & Stand. dev. & Coef. of variation \\
\hline X1 & 56.75 & 55.77 & 15.44 & 107.34 & 25.06 & 44.15 \\
\hline X2 & 7.89 & 8.10 & 5.20 & 9.80 & 1.03 & 13.10 \\
\hline X3 & 65.00 & 65.50 & 52.20 & 78.10 & 7.90 & 12.15 \\
\hline X5 & 56.38 & 58.49 & 31.16 & 73.21 & 10.14 & 17.98 \\
\hline X6 & 51.29 & 49.11 & 32.56 & 74.87 & 11.32 & 22.07 \\
\hline X7 & 2639.31 & 2633.74 & 2427.79 & 2910.37 & 125.36 & 4.75 \\
\hline X8 & 14.64 & 28.90 & 16.10 & 40.70 & 7.08 & 24.73 \\
\hline X9 & 27747.02 & 27512.81 & 21623.22 & 35977.33 & 3353.90 & 12.08 \\
\hline X10 & 11.84 & 11.90 & 9.00 & 15.30 & 1.58 & 13.32 \\
\hline X11 & 42.21 & 36.00 & 17.00 & 92.00 & 17.46 & 41.36 \\
\hline X12 & 6.87 & 6.62 & 3.98 & 10.27 & 1.69 & 24.64 \\
\hline X13 & 116.78 & 107.55 & 66.90 & 182.18 & 29.27 & 25.07 \\
\hline X14 & 37.44 & 37.00 & 29.46 & 46.62 & 4.12 & 11.02 \\
\hline X15 & 50.34 & 51.27 & 25.60 & 68.45 & 11.49 & 22.83 \\
\hline X16 & 782.16 & 754.00 & 635.00 & 987.00 & 91.90 & 11.75 \\
\hline X17 & 0.37 & 0.33 & 0.13 & 0.63 & 0.146 & 39.24 \\
\hline
\end{tabular}

17 attributes were grouped. In order to estimate the distance between clusters, the variance analysis approach is applied. This method aims to minimise the sum of squared deviations inside the clusters. All the indices considered were previously standardised according to formula 2 (Stec et al., 2005):

$$
z_{i j}=\frac{x_{i j}-\overline{x_{j}}}{S\left(x_{j}\right)}
$$

where: $i=1, \ldots, \mathrm{m}$

$$
j=1, \ldots, \mathrm{n}
$$$$
\overline{x_{j}}=\frac{1}{m} \sum_{i=1}^{m} x_{i j}, S\left(x_{j}\right)=\sqrt{\frac{1}{m}} \sum_{i=1}^{m}\left(\left(x_{i j}-\bar{x}_{j}\right)^{2}\right)
$$ 


\section{RESULTS}

The resulting dendrogram clustering the analysed administrative units (poviats) is shown in Figure 4 . The cut-off was performed at the eighth linkage level, which helped to distinguish four sets of objects with similar determinants considering the exposure, vulnerability and adaptive capacity.

Ward's method analysis showed that two clusters comprising three poviats each, one cluster comprising four poviats, and one cluster comprising nine poviats were distinguished (Figure 5). The first cluster comprises Iławski, Nowomiejski and Elbląski Poviats situated in the western part of Warmia and Mazury. The second cluster comprises Ełcki, Giżycki and Olsztyński Poviats located in the central and eastern part of the province. The third cluster comprises Lidzbarski, Działdowski, Gołdapski, Nidzicki, Olecki, Ostródzki, Piski, Szczycieński and Mrągowski
Poviats situated in the southern and, partially, in the north-eastern part of the province. The fourth cluster comprises poviats located in the northern part of the region, including Bartoszycki, Braniewski, Kętrzyński and Węgorzewski.

The distinguished clusters formed subregions with similar determinants of exposure, vulnerability and adaptive capacity in relation to climate change. In the distinguished clusters, average values of the analysed indices were calculated (Table 3), which helped to indicate the spaces differing in attributes.

In the first subregion (cluster S.1), there are considerably more financial losses in areas under agricultural cultivation per ha of agricultural land, almost two times more than in subregion S.4 (PLN 72.73 per ha of agricultural land). In the cluster, there are the best conditions for agricultural production, taking into account the soil, climate, terrain and water relations - the average Agricultural Production Space Ratio has a value

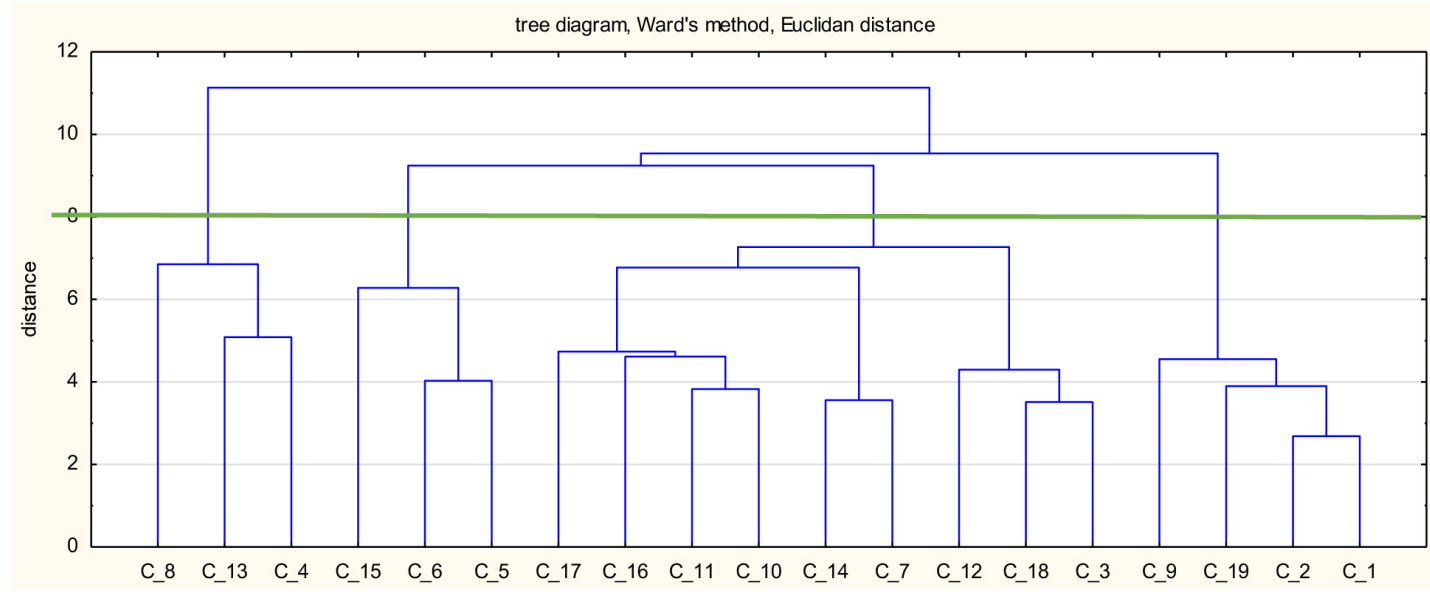

Figure 4. A dendrogram clustering units with similar vulnerability to climate change [Statistica v. 13.1]

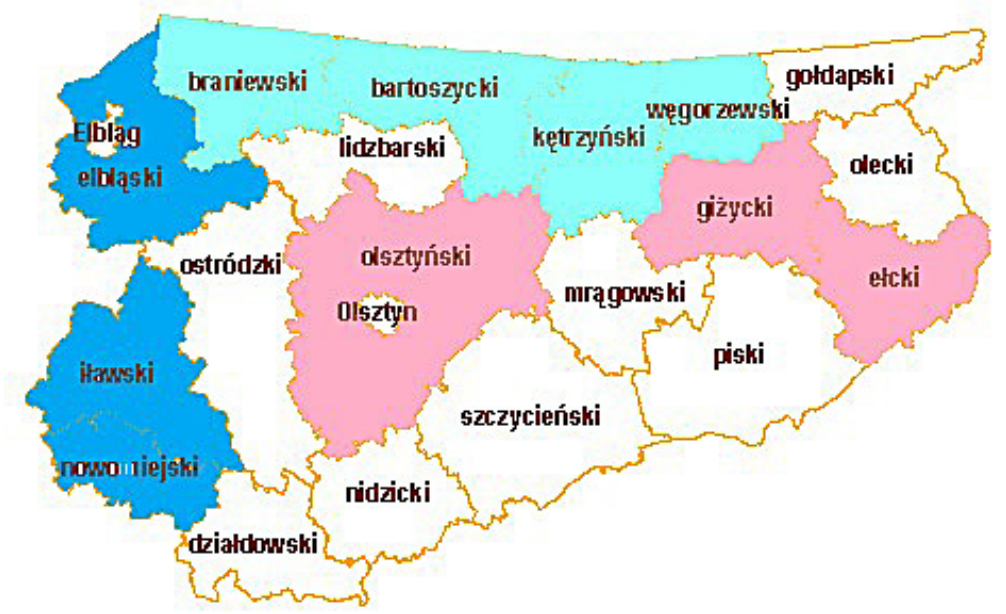

Figure 5. The clustering of poviats in terms of vulnerability to climate change, taking into account the exposure, vulnerability and adaptive capacity (cluster 1 - indigo, cluster 2 - blue, cluster 3 - white, cluster 4 - pink) 
of 74.07 (Poland's average is 66.6). The subregion is characterised by the lowest rural population index $(46.03 \%)$; a majority of these people are employed in agriculture/forestry/fisheries (almost 35\%). It also has the lowest unemployment rate of over $20 \%$. In this group of poviats, the number of people who are able to provide medical care in emergency situations is the greatest ( 8.06 per 1000 inhabitants). The space is also characterised by the highest urbanisation rate (53.98\%) and the smallest number of national economy entities. This is due to the locational causes, since in the west the subregion borders the Pomorskie Province whose capital city along with the neighbouring cities (Tri-City) is one of the major economic centres of Northern Poland. It also offers excellent transport (rail and road) connections which encourages people to transfer their business to that region.

The second cluster includes a subregion with the highest percentage of agricultural land $(65.63 \%)$, the highest yields of major agricultural crops $(42.55 \mathrm{dt} / \mathrm{ha})$ and the highest population of rural area inhabitants $(62.78 \%)$. It also has the highest road density $\left(42.55 \mathrm{~km} / 100 \mathrm{~km}^{2}\right)$ with the lowest urbanisation rate (37.63\%). The unemployment rate $(10.4 \%)$, the percentage of people with tertiary education $(9.87 \%)$, medical care (8.1/1000 inhabitants) and the social capital $(0.24)$ are the lowest levels of all analysed subregions. In geographical terms, the subregion is not a uniform area.

The third subregion (S.3) includes areas with the poorest agro-climatic conditions (7.56) and the lowest Agricultural Production Space Ratio (59.79) which is below the national average. Moreover, the lowest percentage of agricultural land (59.79\%), the lowest GDP per capita and the lowest yield per hectare (34.77 dt per ha of agricultural land) can be observed in this cluster. In terms of the surface, the subregion covers the largest area.

The fourth subregion (S.4) includes areas with the best features representing the adaptive capacity. The following are found there: the highest average salary in agriculture (PLN 2760.46) and the GDP per capital level (PLN 31 389.39); the space is characterised by the highest percentage of population with tertiary education $(14.63 \%)$, the greatest number of schools (61.33) and the greatest number of national economy entities (881 per 10,000 inhabitants). The latest index promotes the multifunctionality of rural areas [Salamon, 2010] and indicates high activity in generating alternative income sources. The index representing social capital is at the highest level $(0.57)$ as well, which indicates the local community's willingness to get involved in carrying out activities for the benefit of the society.

The global climate policy aims at a reduction in greenhouse gas emissions and at the average citizen's use of renewable energy in 100\% [Burck et al., 2018]. If particular countries are fulfilling these two objectives, the ongoing climate change will be minimised. A wide range of globally developed indices enables the identification of not only particular country's exposure to climate

Table 3. Summary of average values of diagnostic features in the analysed cluster

\begin{tabular}{|c|c|c|c|c|c|c|c|c|c|c|c|c|c|c|c|c|c|c|}
\hline $\begin{array}{c}\text { Number } \\
\text { of } \\
\text { cluster }\end{array}$ & Specification & X1av & X2av & X3av & X4av & X5av & X6av & X7av & X8av & X9av & X10av & X11av & X12av & X13av & X14av & X15av & X16av & X17av \\
\hline S.1 & \begin{tabular}{|l|} 
elblaski \\
iławski \\
nowomiejski
\end{tabular} & 72.73 & 8.27 & 74.07 & 61.29 & 46.03 & 2625.63 & 34.75 & 20.25 & 29529.71 & 11.97 & $\underline{30.75}$ & 8.06 & 104.16 & 37.81 & 53.98 & $\underline{729.0}$ & 0.34 \\
\hline S.2 & $\begin{array}{l}\text { ełcki } \\
\text { giżycki } \\
\text { olsztyński }\end{array}$ & 54.44 & 8.60 & 68.60 & 65.63 & 62.78 & 2491.78 & 31.20 & 10.40 & 26257.35 & $\underline{9.87}$ & 43.67 & $\underline{5.10}$ & 116.45 & 42.55 & $\underline{37.63}$ & 730.0 & $\underline{0.24}$ \\
\hline S.3 & \begin{tabular}{|l|} 
lidzbarski \\
ostródzki \\
działdowski \\
nidzicki \\
szczycieński \\
mragowski \\
piski \\
olecki \\
gołdapski \\
\end{tabular} & 54.94 & $\underline{7.56}$ & $\underline{59.79}$ & $\underline{59.79}$ & 50.86 & 2654.18 & 27.23 & 13.43 & 26237.14 & 11.50 & 40.44 & 6.55 & 114.26 & 34.77 & 52.10 & 790.0 & 0.36 \\
\hline S.4 & \begin{tabular}{|l|} 
bartoszycki \\
braniewski \\
kętrzyński \\
węgorzewski
\end{tabular} & $\underline{45.20}$ & 7.66 & 64.90 & 64.90 & 48.10 & 2760.46 & $\underline{22.17}$ & 12.63 & 31389.39 & 14.63 & 61.33 & 8.01 & $\underline{98.12}$ & 39.85 & 52.92 & 881.0 & 0.57 \\
\hline
\end{tabular}


change but also of the level of measures taken by each of these countries to minimise the changes. Most of these indices are global and international in scope, which impedes undertaking local initiatives. The local community's involvement in initiatives, including those aimed at tackling climate change, occurs most frequently in two cases. Firstly, when the legislation or local regulations demand certain actions, and a lack of action is followed by the imposition of penalties. The second case takes place where an individually feels a loss occurring in a household. The distinguishing of uniform groups of units while taking into account not only spatial, economic and agro-climatic determinants [Kocur-Bera, 2015] but also the social capital features (in terms of both vulnerability and adaptive capacity) primarily allows the analysed problem to be addressed more broadly to include the social aspect. If we formulate a hypothesis that it is humans who have largely led to climate change through their actions, then it is also they who should cooperate as regards the trends of actions, strategies and solutions to tackle the phenomenon.

\section{CONCLUSIONS}

Climate change can be observed in numerous aspects of everyday life. Humanity significantly contributes to the climate change process through changing the Earth's surface (in particular improvements on land and hardening) and greenhouse gas emissions to the atmosphere [KocurBera, 2016]. Analyses of the rural space's predisposition to climate change has been the subject of numerous studies worldwide. Countries are at risk to various degrees. Global indices show the highest vulnerability of Asian and Latin American countries [Eckstein et al., 2018].

The aim of the study was to distinguish units in Warmia and Mazury which are similar in terms of the predisposition to climate change. The study took into account the "vulnerability" represented by the units' exposure, sensitivity and adaptive capacity. Each domain was expressed by 2-10 indices which were collected for each analysed administrative unit. Four clusters (subregions) with different numbers of units (poviats) were distinguished. Two clusters (S.1 and S.2) stand out due to the high exposure and vulnerability to climate change, as the indices reflecting these domains have the lowest value. One subregion (S.4) represents high adaptive capacity, since as many as five indices have the maximum value.

Areas used for agricultural purposes in Poland belong to a group of the most vulnerable areas since production there is primarily based on natural weather conditions. Therefore, a very important process aimed at extending prevention and adaptation measures is a diagnosis of the land. The indication of subregions with common features representing the vulnerability to climate change is an element that allows decision-makers to redirect their attention to the need for strengthening both the space and the resilience of rural communities.

\section{REFERENCES}

1. Błażejczyk K., Żmudzka E., 2013. Global climate change - overview after 25 years of IPCC. Kosmos 62/ 1, 1-11 (in Polish).

2. Bryan, E., Ringler, C., Okoba, B., Roncoli, C., Silvestri, S., Herrero, M., 2013. Adapting agriculture to climate change in Kenya: household strategies and determinants. J. Environ. Manag. 114, 26-35.

3. Burck J., Hagen U., Marten F., Höhne N., Bals Ch., 2018. CCPI Results 2019. Germanwatch, NewClimate Institute \& Climate Action Network, ISBN 978-3-943704-68-6.

4. Ciołek D., Brodzicki T., Szlachta J., 2018. Estimates of GDP in poviats of the Warmian-Masurian Voivodeship as well as conclusions and recommendations for planning the future of regional policy of the voivodship in the time horizon up to 2030. Meeting of the Monitoring Committee for the implementation of the Social and Economic Development Strategy of the Warmian-Masurian Voivodship by 2025, Olsztyn, 11-07-2018 r, [Accessed 11-03-2019] (in Polish).

5. Coumou, D. and S. Rahmstorf. 2012. A decade of weather extremes. Nature Climate Change 2: 491-496.

6. Cardona O.D., Van Aalst M.K., Birkmann J., Fordham M., Mcgregor G., Perez R., Pulwarty R.S., Schipper E.L.F., Sinh B.T., 2012: Determinants of Risk: Exposure And Vulnerability. In: Managing the Risks Of Extreme Events And Disasters To Advance Climate Change Adaptation [Field, C.B., V. Barros, T.F. Stocker, D. Qin, D.J. Dokken, K.L. Ebi, M.D. Mastrandrea, K.J. Mach, G.-K. Plattner, S.K. Allen, M. Tignor, And P.M. Midgley (Eds.)]. A Special Report of Working Groups I And II of The Intergovernmental Panel on Climate Change (Ipcc). Cambridge University Press, Cambridge, Uk, And New York, Ny, Usa, pp. 65-108. 
7. Eckstein D., Hutfils M-L, Winges M., 2018. Global climate risk index 2019. Who Suffers Most from Extreme Weather Events? Weather-related Loss Events in 2017 and 1998 to 2017. Think Tank \& Research, GermanWatch, https://germanwatch.org [accessed 14-03-2019].

8. EEA 2017. Report no 1/2017 climate change, impacts and vulnerability in Europe 2016 an indicator-based report. Publications office of the European Union, Luxembourg.

9. Granados, A. 2012. Estimate Social Vulnerability Index to climate change in Mexico. Population Association of America 2012 annual meeting. San Francisco, CA, 3-5 may, 2012.

10. Hahn M, Reiderer A., Foster S., 2009. The Livelihood Vulnerability Index: A pragmatic approach to assessing risks from climate variability and change-A case study in Mozambique, Global Environmental Change 19 (2009), 74-88.

11. Hiremath D., B., Shiyani R.L., 2013. Analysis of Vulnerability Indices in Various Agro-Climatic Zones of Gujarat. Ind. Jn. of Agri. Econ. Vol. 68, No. 1, Jan.-March 2013.

12. IPCC 2018. The Intergovernmental Panel on Climate Change (IPCC) - report. https://www.ipcc.ch/ [Accessed 13-03-2019].

13. Kocur-Bera K., 2016. Convergence of spatial characteristics areas exposed to effects of extreme events. Administratio Locorum 15/4, DOI: https:// doi.org/10.31648/aspal.659 (in Polish).

14. Kocur-Bera K., 2018. A safe space of rural areas in the context of the occurrence of extreme weather events - a case study covering a part of the Euroregion Baltic. Land Use Policy 71, 518-529; https:// doi.org/10.1016/j.landusepol.2017.11.013.

15. Kocur-Bera K., 2015. Identification subpopulations with similar characteristics in terms of extreme weather events. Acta Scientarum Polonorum, Administratio Locorum 14/3, 75-89 (in Polish)

16. Kundzewicz Z.W., 2011. Climate changes, their reasons and effects - observations and projections. Landform Analysis 15, 39-49 (in Polish);

17. Ludena C.E., Won Yoon S., 2015. Local Vulnerability Indicators and Adaptation to Climate
Change. A Survey. Climate Change and Sustainability Division, Technical Note N. 857.

18. ODR, 2016. Yields of main crops - harvest in 2016. Collective harvesting of crops from 19 poviats in the province Warmia-Mazury. www.w-modr.pl [Accessed 11-03-2019] (in Polish).

19. ODR, 2018. List of financial losses due to natural disasters. Unpublished materials (in Polish).

20. Pawlewicz K., 2014. Relationships between social capital and socio-economic development based on rural communes in the warmińskomazurskie voivodeship. Journal of Agrobuissnes and Development 3(41), 373-381, DOI: 10.17306/ JARD.2016.65.

21. Polsky, C., Neff, R., Yarnal, B., 2007. Building comparable global change vulnerability assessments: the vulnerability scoping diagram. Glob. Environ. Change 17 (3e4), 472e485.

22. Ritchie H., Roser M., 2019. Natural Disasters. Source: https://Ourworldindata.Org/Natural-Disasters' [Accessed 06-03-2019].

23. Rudnicki R., Kluba M., 2014. Integrated rural development in the light of EU policy. T.1, Nicolaus Copernicus University in Torun (in Polish).

24. Stec M., Janas A., Kuliński A., 2005. Grouping the Countries of European Union with Regard to the Human Capital Resources. Nierówności Społeczne a Wzrost Gospodarczy vol. 6, pp. 135-146, YADDA: bwmeta1.element.ekon-element-000171212151, (in Polish);

25. Sridevi G., Jyotishi A., Mahapatra S., Jagadeesh G., Bedamatta S., 2014. Climate Change Vulnerability in Agriculture Sector: Indexing and Mapping of Four Southern Indian States. Quaderni - Working Paper DSE No. 966, p. 32, Italy.

26. Salamon J., 2010. Methodology for assessment of environmental and socio-economic conditionings of multifunctional rural development. University of Agriculture in Kraków, (in Polish).

27. Žurovec O., Cadro S., Sitaula B.K., 2017. Quantitative Assessment of Vulnerability to Climate Change in Rural Municipalities of Bosnia and Herzegovina. Sustainability 9, 1208; doi:10.3390/ su9071208; 